\title{
DESKRIPSI DAMPAK GEMPA BUMI DAN LIKUIFAKSI TERHADAP PETANI DI DESA JONO OGE KABUPATEN SIGI PROPINSI SULAWESI TENGAH
}

\author{
Description of Earthquake and Liquefaction Impacts on Farmers in Jono Oge Village \\ Sigi at Central of Sulawesi
}

\author{
Karlina Muhsin Tondi \\ Program Studi Agribisnis Fakultas Pertanian Universitas Tadulako \\ Jln. Soekarno Hatta km. 09 Palu, Sulawesi Tengah \\ *Email Korespondensi: karlinamuhsin81@gmail.com
}

\begin{abstract}
The purpose of this study was to describe the impact of earthquakes and liquefaction on farmers in Jono Oge village, Sigi regency, Central Sulawesi province. This research was a qualitative descriptive study using questionnaire and interview instruments. Information was also obtained through literature study and field observations. The subjects of this study were farmers in Jono Oge village, Sigi regency. Respondents were purposively selected. The questionnaires consisted of ten questions which had been validated by experts. The questionnaires were given to ten farmers while the interview was conducted on four farmers. The literature study was carried out by tracing information on the Sigi Regency BPS Office, Jono Oge Village Office and a number of online media reporting on earthquakes and liquefaction that occurred in Central Sulawesi on 28 September 2018. The observations were made on such land affected by earthquakes and liquefaction. These observations were also carried out on irrigation channels and cultivated land in the area of liquefaction. It was found that around 250 ha cultivated agricultural land had been destroyed due to the liquefaction as well as the irrigation canals used to distribute water to the cultivated land had been damaged. The disappearance of the cultivated land had led the farmers to rent agricultural land in the nearby villages such as Lolu, Sidera and Pombewe in order for them to sustain their livelihood. The source of water for irrigation was ground water pumping by Alcon equipment donated by several organizations. The farmers' income was also decreased by almost $50 \%$. Thus it was concluded that the earthquake and liquefaction had a significant impact on the lives of farmers in Jono Oge Village.
\end{abstract}

Keywords: Earthquakes, Farmers, Jono Oge and Liquefaction.

\begin{abstract}
ABSTRAK
Tujuan penelitian ini adalah untuk mendeskripsikan dampak gempa bumi dan likuifaksi terhadap petani di Desa Jono Oge Kabupaten Sigi Propinsi Sulawesi Tengah. Penelitian ini merupakan penelitian deskriptif kualitatif dengan instrumen angket dan wawancara. Informasi juga diperoleh melalui studi dokumen dan observasi lapangan. Subjek penelitian ini adalah petani di Desa Jono Oge Kabupaten Sigi. Teknik pemilihan responden dilakukan dengan pertimbangan tertentu (purposive sampling). Angket yang berisi sepuluh pertanyaan dan telah divalidasi oleh ahli diberikan kepada sepuluh orang petani. Selain itu, wawancara dilakukan pada empat orang petani di desa tersebut. Studi dokumen dilakukan dengan menelusuri informasi pada Kantor BPS Kabupaten Sigi, Kantor Desa Jono Oge dan sejumlah media online yang memberitakan gempa bumi dan likuifaksi yang terjadi di Sulawesi Tengah pada tanggal 28 September 2018. Observasi dilakukan pada lahan yang terdampak gempa bumi dan likuifaksi. Observasi ini juga dilakukan pada saluran irigasi yang rusak serta lahan yang diolah oleh petani saat ini. Dari hasil penelitian diketahui bahwa luas lahan pertanian yang hilang sekitar $250 \mathrm{Ha}$ dan saluran irigasi yang digunakan oleh petani selama ini mengalami kerusakan. Untuk tetap dapat melakukan profesi sebagai petani, mereka
\end{abstract}


menyewa lahan pertanian yang ada di desa terdekat seperti Desa Lolu, Sidera dan Pombewe. Sumber air berupa air tanah digunakan dan irigasinya dibantu dengan peralatan Alcon yang disumbangkan oleh beberapa organisasi. Pendapatan petani juga mengalami penurunan hingga hampir $50 \%$. Dengan demikian disimpulkan bahwa adanya bencana gempa bumi dan likuifaksi sangat berdampak terhadap kehidupan petani di Desa Jono Oge Kabupaten Sigi.

Kata Kunci: Gempa Bumi, Jono Oge, Likuifaksi, dan Petani.

\section{PENDAHULUAN}

Secara geografis, Pulau Sulawesi terletak pada $5.36^{\circ} \mathrm{LU}-7.48^{\circ} \mathrm{S}$ and $117.02^{\circ}$ $125.74^{\circ} \mathrm{E}$ (Wekke et al, 2019). Sulawesi Tengah merupakan salah satu provinsi di Pulau Sulawesi yang terdiri dari 1 kota dan 12 kabupaten. Komoditas pertanian yang dihasilkan berupa padi, coklat, cengkeh, kopra dan lain-lain. Selain Kabupaten Parigi Moutong, Kabupaten Sigi merupakan daerah pertanian yang banyak menyuplai bahan pangan pada masyarakat di Sulawesi Tengah (BPS Sulteng, 2018). Olehnya, kabupaten ini memiliki peran penting dalam memasok tanaman pangan di Sulawesi Tengah.

Bencana alam yang terjadi di Kota Palu, Kabupaten Donggala dan Sigi pada 28 September 2018 berupa gempa bumi diiringi tsunami dan likuifaksi menjadi salah satu fenomena yang dianggap cukup menarik karena belum pernah terjadi di daerah manapun di Indonesia (Sassa and Tagawa, 2019; Valkaniotis et al, 2019). Adanya tiga jenis bencana alam yang terjadi pada waktu yang beriringan ini sangat berdampak pada kehidupan masyarakat dan menarik untuk dikaji sehingga dapat dipikirkan antisipasi dan solusinya di masa mendatang.

Likuifaksi terjadi pada beberapa tempat di Sulawesi Tengah seperti Balaroa, Petobo dan Jono Oge. Sebagai fenomena yang ditandai dengan amblasnya permukaan tanah, peristiwa ini mengakibatkan ratusan hektar lahan pertanian di Kabupaten Sigi menjadi hilang dan rusak (Bao et al, 2019). Jono Oge merupakan salah satu desa yang mengalami kerusakan paling parah di antara daerah lain di Kabupaten Sigi tersebut. Dimana Jono Oge merupakan salah satu desa yang memiliki lahan pertanian yang cukup luas ( \pm 436,87 Ha). Menariknya dalam foto pada Gambar 1 diperlihatkan adanya pergeseran tanah di Desa Jono Oge. Dimana tanah yang semula kosong berubah menjadi kebun jagung dan pohon kelapa. Adanya fenomena pergeseran tanah di Desa Jono Oge merupakan fenomena yang sangat menarik untuk dikaji khususnya dampak terhadap kehidupan masyarakat seperti para petani yang mayoritas ada di desa tersebut.

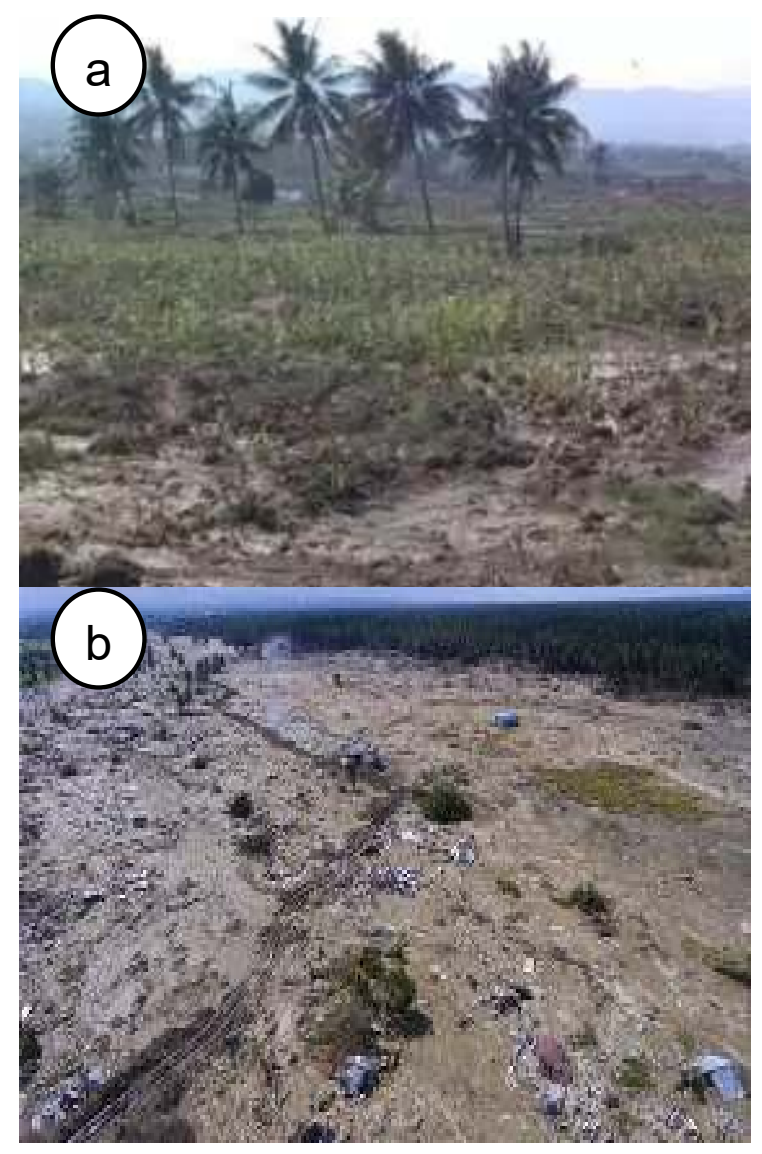

Gambar 1.(a) Foto lokasi Desa Jono Oge yang telah hilang dan berubah menjadi kebun jagung dan pohon kelapa (http://www.sketsanews.com); dan (b) Foto udara Desa Jono Oge (http://www.foto.tempo.co). 
Setelah hampir delapan bulan berlalu, hingga saat ini sejumlah makalah telah melaporkan tentang gempa bumi, tsunami dan likuifaksi yang terjadi di Palu, Kabupaten Sigi dan Donggala pada 28 September 2018. Akan tetapi, diantara studi tersebut belum ada yang melaporkan kajian tentang dampak bencana dahsyat ini pada para petani yang berada di Kabupaten Sigi Sulawesi Tengah. Hal inilah yang membuat peneliti tertarik untuk menulis artikel ini karena dampak gempa bumi dan likuifaksi terhadap petani di daerah yang tertimpa bencana sangat penting untuk dibahas karena berkaitan dengan perekonomian dan ketahanan pangan Sulawesi Tengah. Hasil penelitian ini juga diharapkan dapat menjadi salah satu referensi bagi penelitian selanjutnya berkaitan dengan petani terdampak bencana alam.

Tujuan penelitian ini adalah untuk: (1) mendeskripsikan dampak gempa bumi dan likuifaksi terhadap petani di Desa Jono Oge Kabupaten Sigi Provinsi Sulawesi Tengah; (2) mengetahui pendapatan petani sebelum dan sesudah gempa bumi dan likuifaksi; (3) mengetahui upaya yang ditempuh petani setelah gempa bumi dan likuifaksi; dan (4) mengidentifikasi faktor pendukung kehidupan petani setelah terjadinya gempa bumi dan likuifaksi.

\section{METODE PENELITIAN}

Penelitian yang dilaksanakan di Desa Jono Oge Kecamatan Sigi Biromaru ini merupakan penelitian deskriptif kualitatif. Populasi penelitian ini adalah seluruh petani di Desa Jono Oge yang terdampak gempa bumi dan likuifaksi yang berjumlah sekitar 1.892 orang. Diasumsikan bahwa populasi bersifat homogen. Responden penelitian berjumlah sepuluh orang dipilih dengan pertimbangan tertentu (purposive sampling) yaitu petani Desa Jono Oge yang terkena dampak gempa bumi dan likuifaksi pada 28 September 2018 dan telah kembali melakukan aktivitas bertani sejak masa tanggap darurat dinyatakan berakhir oleh pemerintah. Data yang digunakan dalam penelitian ini bersumber dari data primer dan data sekunder. Data primer diperoleh melalui angket, wawancara dan pengamatan (observasi) sedangkan data sekunder diperoleh melalui studi pustaka baik pustaka yang sifatnya online maupun offline (Saputra dkk, 2018). Instrumen penelitian adalah angket dan panduan wawancara. Angket yang telah divalidasi tersebut diberikan kepada sepuluh orang responden dan untuk memperoleh informasi yang lebih mendalam maka empat orang responden tersebut diwawancarai secara mendalam (in-depth interview). Selain itu, data juga diperoleh melalui studi pustaka dan pengamatan langsung di lapangan. Pengolahan data yang diperoleh melalui angket dilakukan dengan menggunakan teknik persentase (Arisena, 2018). Sedangkan data dari hasil wawancara digunakan untuk menjelaskan beberapa data yang diperoleh melalui angket. Data dari hasil observasi lapangan dan studi pustaka digunakan sebagai pelengkap.

\section{HASIL DAN PEMBAHASAN}

\section{Deskripsi Kondisi Masyarakat Desa Jono} Oge sebelum Terjadinya Gempa Bumi dan Likuifaksi. Kabupaten Sigi memiliki 15 kecamatan dan 14 diantaranya merupakan kecamatan penghasil beras. Kecamatan Sigi Biromaru merupakan salah satu daerah penghasil beras terbesar di Kabupaten Sigi. Kecamatan ini merupakan kecamatan dengan areal panen terluas yaitu 9.784 ha dengan tingkat produktivitas 4,84 ton/ha. Desa Jono Oge terletak di Kecamatan Sigi Biromaru dan berbatasan dengan Desa Lolu di sebelah utara dan Desa Sidera pada bagian selatan. Di bagian barat dan timur desa ini masing-masing berbatasan dengan Desa Langaleso dan Desa Pombewe. Berdasarkan data BPS Provinsi Sulawesi Tengah diketahui bahwa jumlah penduduk Desa Jono Oge awal Tahun 2018 sekitar 2.262 orang yang terdiri dari $56 \%$ laki-laki (1.262 orang) dan $44 \%$ perempuan (1.000 orang). Sebanyak $84 \% \quad(1.892$ orang) penduduk Desa Jono Oge berprofesi sebagai petani. Sisanya yaitu sebesar $16 \%$ menekuni profesi lain terbagi atas pedagang 
sebesar 4\% (97 orang), sopir sebesar $0,5 \%$ (13 orang), buruh sebesar 4,8\% (109 orang), PNS sebesar 2\% (47 orang), TNI sebesar $0,3 \%$ (6 orang), POLRI sebesar $0,4 \%$ (10 orang) dan wiraswasta sebesar $4 \% \quad(88$ orang). Etnis yang terdapat di desa ini terdiri dari Kaili, Jawa, Bugis, Manado, Makassar, dan Toraja. Tingkat pendidikan masyarakat berdasarkan lulusan pendidikan umum adalah sebanyak 3,51\% (110 orang) tamatan TK, sebesar 16,31\% (513 orang) tamatan SD, sebesar $31.10 \%$ (976 orang) tamatan SMP, sebesar 28,04\% (880 orang) tamatan SMA, sebanyak 0,9\% (27 orang) tamatan akademi (D1 hingga D3), sebesar $4,84 \%$ (152 orang) sarjana dan pascasarjana. Jumlah masyarakat yang tidak sekolah adalah 15,3\% (480 orang). Luas sawah dengan irigasi teknis adalah $186 \mathrm{Ha}$. Dimana tanaman padi merupakan tanaman yang banyak dihasilkan oleh petani. Sumber air diambil dari aliran sungai gumbasa dan irigasi menggunakan sistem pengairan berganti yang diprogramkan oleh pemerintah Kabupaten Sigi. Foto udara Desa Jono Oge dapat dilihat pada Gambar 2.

Sejak Tahun 2010 sampai 2018 telah terjadi pengalihan fungsi lahan dari tanaman padi sawah menjadi tanaman hortikultura. Petani padi sawah di Desa Jono Oge melakukan pengalihan fungsi lahan dikarenakan proses pengolahan lahan sampai proses pasca panen untuk tanaman hortikultura lebih mudah dibandingkan tanaman padi sawah. Tanaman hortikultura juga tidak membutuhkan terlalu banyak tenaga kerja dalam setiap kegiatan produksinya sehingga dapat mengurangi biaya yang dikeluarkan dan memungkinkan petani untuk memperoleh pendapatan yang lebih besar. Rata-rata pendapatan usahatani padi sawah yang diperoleh oleh petani padi sawah Desa Jono Oge Kecamatan Sigi Kabupaten Sigi Biromaru sebesar Rp. 13.506.959,46 per luas lahan usaha tani (1 ha/MT) (Mulyati, 2014).

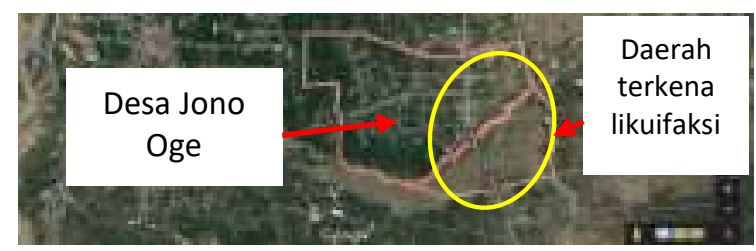

Gambar 2. Foto udara Desa Jono Oge dengan citra satelit yang diambil dengan menggunakan aplikasi google earth (Diakses pada tanggal 21 Mei 2019).

Deskripsi Kondisi Masyarakat Desa Jono Oge setelah Terjadinya Gempa Bumi dan Likuifaksi. Berdasarkan hasil penelitian, umur petani responden tergolong dalam usia tenaga kerja yang produktif. Dimana 8 orang $(80 \%)$ tergolong dalam usia muda dari 25-54 tahun, sedangkan petani yang tergolong lanjut usia hanya sebesar 2 orang (20\%) pada usia 55-84 tahun. Hal ini menjelaskan bahwa tenaga petani responden yang dimiliki tergolong produktif sehingga usahatani di Desa Jono Oge dapat dilakukan dengan baik sehingga produksi dapat ditingkatkan.

Berdasarkan hasil penelitian, jumlah responden yang berpendidikan SD sebanyak 5 orang $(50 \%)$, responden berpendidikan SMP sebanyak 3 orang (30\%), dan responden yang berpendidikan SMA sebanyak 2 orang (20\%). Akan tetapi, selain dari pendidikan formal petani responden juga dapat memperoleh pengetahuan dari pendidikan non formal, seperti penyuluhan, pengalaman selama berusahatani, dan pengetahuan turun temurun yang diperoleh dari orang tua responden sehingga usaha tani yang dilakukan tidak terhambat.

Dari data One Street Map (OSM) Indonesia diketahui bahwa likuifaksi di Desa Jono Oge seluas 436,87 Hektar atau sekitar $10 \%$ dari luas keseluruhan Desa Jono Oge (https://properti.kompas.com). Dari data tersebut diketahui bahwa sekitar $250 \mathrm{Ha}$ adalah lahan pertanian. Data di lapangan menunjukkan bahwa 100\% lahan pertanian rusak berat. Dari data tersebut diketahui bahwa seluruh responden kehilangan lahan pertanian yang dimiliki karena adanya gempa bumi dan likuifaksi. Hasil wawancara dan observasi lapangan juga menunjukkan bahwa batas-batas tanah sudah tidak dapat diidentifikasi dengan jelas. Belum lagi sumber air dan saluran irigasi rusak/tidak tersedia, seperti ditunjukkan oleh Gambar 3, menyebabkan seluruh lahan 
tersebut berubah menjadi lahan kering yang tidak produktif. Dimana diketahui bahwa selama ini lahan pertanian di Desa Jono Oge menggunakan sumber air yang berasal dari Sungai Gumbasa melalui saluran irigasi yang telah dibangun oleh pemerintah.

Dari hasil observasi di lapangan, diketahui bahwa adanya bencana alam yaitu gempa bumi dan likuifaksi menyebabkan lahan pertanian/sawah menjadi rusak. Dimana struktur bagian atas permukaan tanah tidak rata (ada bagian yang naik dan pada sisi lainnya turun). Adapula bagian tanah yang terbelah atau pecah-pecah. Hal ini bahkan menjadi semakin buruk karena tidak mendapat pasokan air dalam jumlah yang cukup setelah bencana alam terjadi. Kondisi lahan sejumlah $250 \mathrm{Ha}$ tersebut saat ini ditumbuhi rumput dan ilalang seperti ditunjukkan oleh Gambar 4.

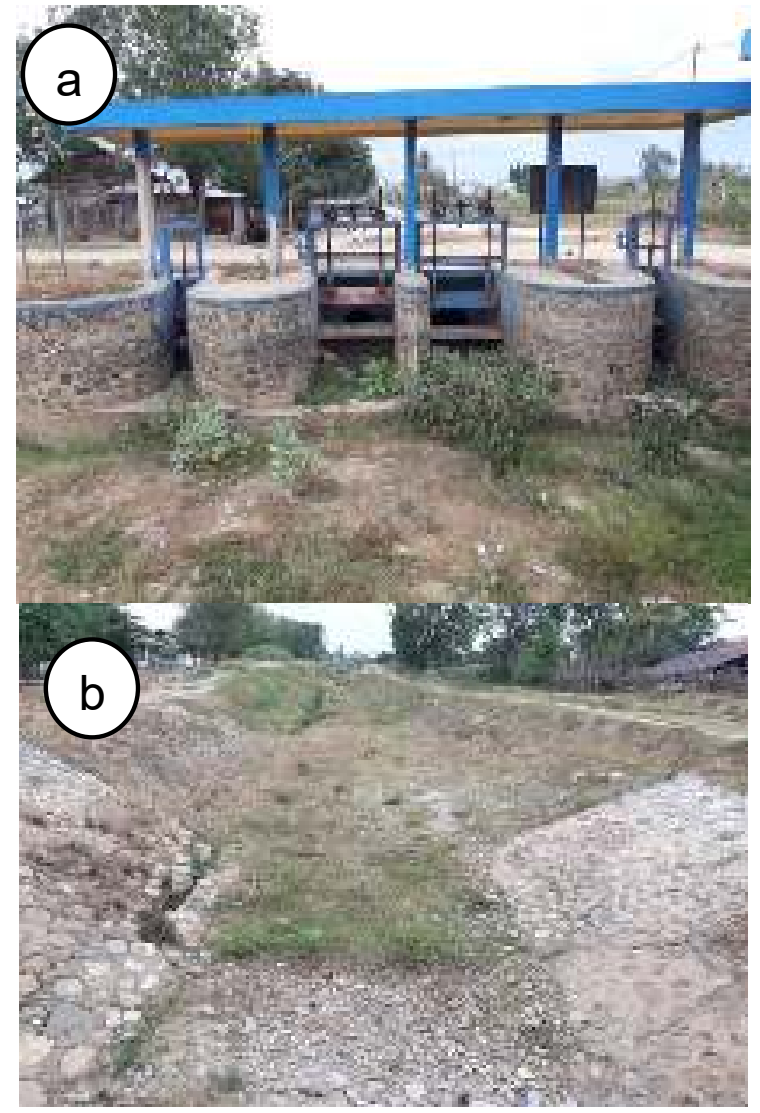

Gambar 3. (a) Pengatur air pada saluran irigasi di Desa Jono Oge yang mengalami kerusakan;

(b) Tanggul pada pada saluran irigasi di Desa Jono Oge
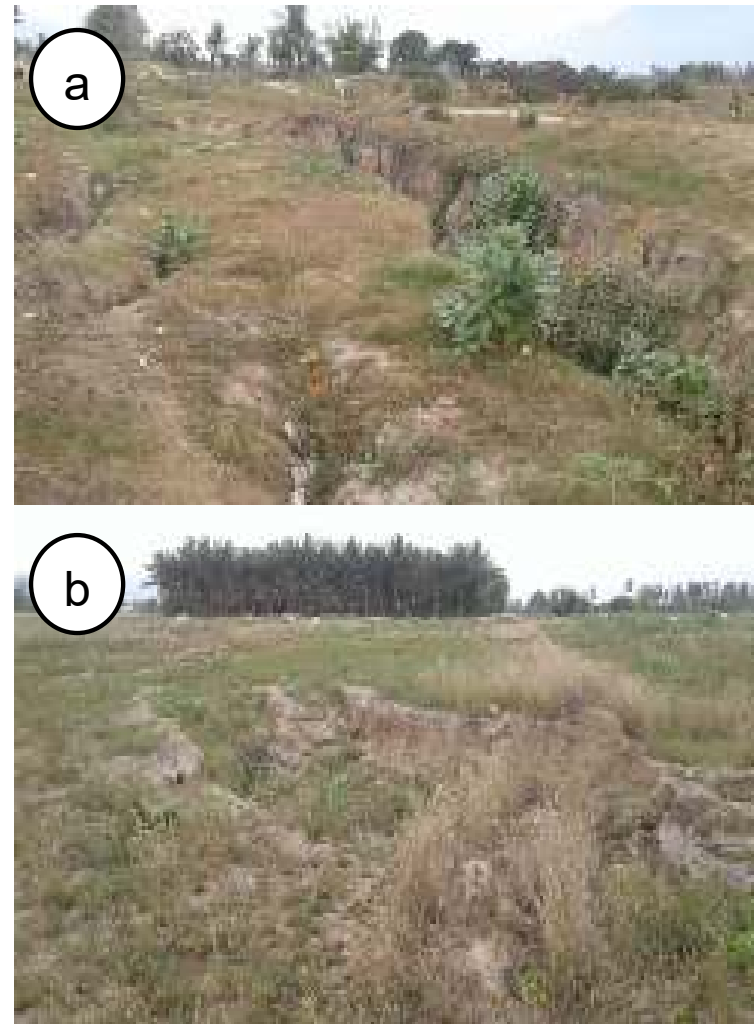

Gambar 4. (a) Tanah pertanian yang terbelah di Desa Jono Oge;

(b) Permukaan tanah yang rusak dan ditumbuhi rumput dan ilalang di Desa Jono Oge.

Adanya bencana alam ini menyebabkan pendapatan petani menjadi menurun. Dari hasil pengolahan angket diketahui perbandingan besarnya penghasilan petani sebelum dan setelah terjadinya gempa bumi dan likuifaksi seperti ditunjukkan pada Tabel 1.

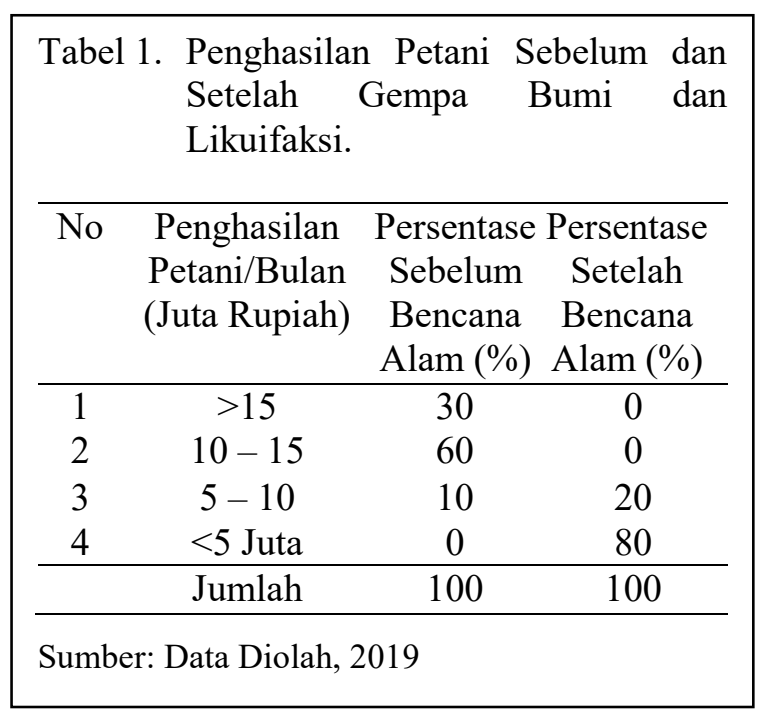


Tabel 2. Tempat Tinggal Petani Desa Jono Oge Setelah Gempa Bumi dan Likuifaksi.

\begin{tabular}{clcc}
\hline No & \multicolumn{1}{c}{ Tempat Tinggal } & $\begin{array}{c}\text { Persenta } \\
\text { se (\%) }\end{array}$ \\
\hline 1 & Hunian & Sementara & 20 \\
& (Huntara) & & 10 \\
2 & Rumah Darurat & 70 \\
3 & Kembali ke Rumah & \\
& Semula \\
4 & $\begin{array}{l}\text { Tidak memiliki tempat } \\
\text { tinggal tetap }\end{array}$ \\
\hline \multicolumn{3}{c}{ Jumlah } & 100 \\
\hline
\end{tabular}

Sumber: Data Diolah, 2019

Dari Tabel 1 diketahui persentase penghasilan petani sebelum terjadinya gempa bumi dan likuifaksi. Dimana sebanyak $30 \%$ petani memiliki penghasilan di atas Rp. 15.000.000,-; sebanyak 60\% petani memiliki penghasilan antara $\mathrm{Rp}$. 10.000 .000 s.d Rp. 15.000.000 dan hanya $10 \%$ petani yang memiliki penghasilan antara Rp. 5.000.000 sd Rp. 10.000.000. Di sisi lain, setelah terjadinya gempa bumi dan likuifaksi ditemukan hanya $20 \%$ petani yang memiliki penghasilan Rp. 5.000.000 s.d Rp. 10.000.000 dan sebanyak 80\% petani menyatakan bahwa penghasilannya di bawah Rp. 5.000.000,--

Selain lahan pertanian, para responden juga kehilangan harta benda dan tempat tinggal. Tabel 2 menunjukkan bahwa dengan adanya gempa bumi dan likuifaksi menyebabkan sebanyak $10 \%$ responden tinggal pada rumah/gubuk darurat (yang dibuat seadanya). Sebanyak $20 \%$ responden menyatakan tinggal di hunian sementara (huntara) dan sebanyak $70 \%$ responden telah kembali ke rumah di Desa Jono Oge mereka walaupun rumah yang ditinggali tersebut dalam kondisi rusak dan belum diperbaiki.

Pola Bertani Masyarakat Desa Jono Oge Setelah Gempa Bumi dan Likuifaksi. Hilangnya lahan pertanian karena adanya gempa bumi dan likuifaksi menyebabkan petani mencari solusi untuk dapat melanjutkan profesi yang ditekuninya tersebut/ mempertahankan diri. Dari hasil wawancara diketahui bahwa agar dapat terus bertani, para petani di Desa Jono Oge mencari lahan pertanian di desa sekitar yaitu Lolu, Pombewe, Solowe, Pedagi, Watunonju dan Kalukubula.

Hasil pengamatan di lapangan memperlihatkan bahwa tidak ada lagi lahan pertanian yang diolah di Desa Jono Oge. Demikian pula, seluruh petani terdampak gempa bumi likuifaksi menyewa lahan masyarakat desa lain yang ada di sekitar Desa Jono Oge. Dari hasil wawancara diketahui bahwa para petani berangkat pada pagi hari sekitar jam 07.00 WITA dan kembali ke rumah sekitar jam 12.00 WITA. Para petani kembali bekerja di lahan pertanian sekitar jam 14.30 dan kembali ke rumah sekitar jam 17.30 WITA. Dengan demikian diperkirakan rata-rata lama waktu bekerja para petani tersebut adalah delapan jam.

Besarnya sewa/tarif yang ditetapkan oleh pemilik lahan pada petani Desa Jono Oge juga bervariasi. Dimana dari hasil pengolahan angket pada Tabel 3 diketahui bahwa rata-rata harga sewa lahan sebesar Rp. 5.000.000 s.d Rp. 10.000.000 setiap hektar per tahun. Hal ini tentu saja sangat kontradiksi dengan keadaan sebelumnya dimana setiap petani memiliki lahan masing-masing untuk diolah dan digunakan tanpa menyewa.

\begin{tabular}{|ccc|}
\hline Tabel 3. $\begin{array}{c}\text { Biaya Sewa Lahan Yang } \\
\text { Digunakan Oleh Petani Desa Jono } \\
\text { Oge }\end{array}$ \\
\hline No & Biaya Sewa Lahan & $\begin{array}{c}\text { Persentase } \\
(\%)\end{array}$ \\
\hline 1 & $>$ Rp. 10.000 .000$, & 0 \\
2 & $\begin{array}{c}\text { Rp. 5.000.000, s.d. } \\
\text { Rp. } 10.000 .000\end{array}$ & 100 \\
3 & $<$ Rp. 5.000 .000 & 0 \\
\hline \multicolumn{3}{c}{ Jumlah } \\
\hline Sumber: Data Diolah, 2019 \\
\hline
\end{tabular}


Sumber air dan irigasi merupakan hal yang sangat penting dan menentukan produksi hasil pertanian (Mulyati, 2014). Dari hasil wawancara diketahui bahwa sekitar $90 \%$ petani menggunakan sumber air yang berasal dari air tanah dengan bantuan alat penghisap bermerek Alcon seperti ditunjukkan oleh Gambar 5. Sebesar $10 \%$ responden menyampaikan bahwa untuk mengairi lahan menggunakan sumber air yang disewa.

Dengan adanya sumber air tanah dan saluran irigasi buatan ini, petani dapat kembali produktif dalam menghasilkan sejumlah tanaman hortikultura seperti kacang panjang, labu madu dan semangka. Namun demikian, adanya peralatan ini juga membutuhkan biaya operasional dan perawatan (maintenance) seperti membeli bahan bakar dan perawatan mesin. Dari hasil wawancara diketahui bahwa seluruh responden mengatakan bahwa untuk mengairi lahan dibutuhkan rata-rata $\mathrm{Rp}$. 100.000/hari untuk membeli bahan bakar berupa bensin. Hal ini membuat biaya operasional (komponen pengeluaran) petani juga mengalami peningkatan.Di sisi lain, hal ini tentu saja membuat penghasilan petani menjadi menurun yaitu menjadi $<$ Rp. 5 juta per bulan. Seluruh responden mengatakan bahwa penghasilan yang diperoleh hanya cukup untuk memenuhi kebutuhan sehari-hari yaitu makan, memperbaiki tempat tinggal yang rusak, membeli perabot dan menyekolahkan anak. Petani tidak bisa menyimpan uang untuk keperluan yang sifatnya mendesak.

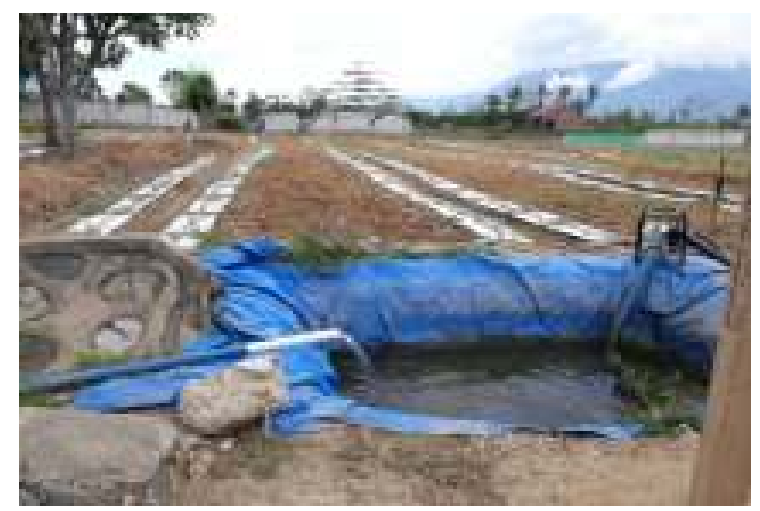

Gambar 5. Irigasi Petani Desa Jono Oge dengan Menggunakan Peralatan Alcon.
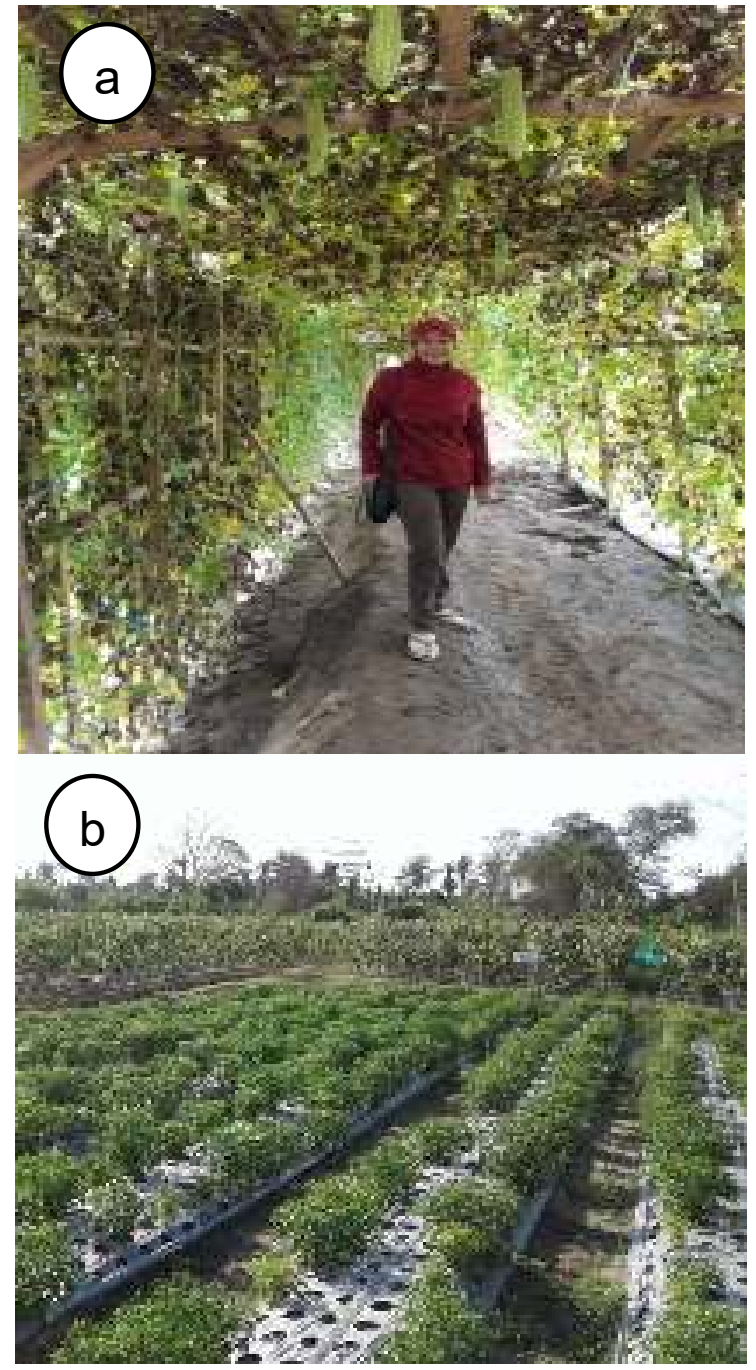

Gambar 6 (a) Tanaman Sayur dan

(b) Tanaman Cabe yang Ditanam oleh Petani dengan Irigasi Buatan.

Gambar 6 menunjukkan keberhasilan petani dalam menanam kembali lahan pertanian. Selain itu, komoditas pertanian secara umum sedikit mengalami perubahan setelah bencana alam terjadi. Diketahui bahwa sekitar $20 \%$ dari petani mempertahankan jenis tanaman yang dibudidayakan sebelum terjadinya gempa bumi dan likuifaksi. Selanjutnya, sebesar $80 \%$ dari responden menyatakan bahwa petani memilih membudidayakan tanaman yang biaya produksinya rendah (harga bibit murah dan cepat panen). Meskipun mayoritas tingkat pendidikan masyarakat petani di Desa Jono Oge adalah tamatan SMP namun para petani tersebut telah mengenal metode irigasi dan teknologi 
pertanian melalui jalur informal (pengetahuan turun-temurun, pelatihan serta penyuluhan).

Gambar 6 (a) adalah tanaman sayur paria yang dibudidayakan oleh petani dengan menggunakan saluran irigasi buatan.Tanaman cabe, seperti ditunjukkan oleh Gambar 6 (b), dibudidayakan oleh petani karena harga bibitnya rendah dan cepat dipanen.

\section{Peran Pemerintah Dalam Mengatasi Masalah Pertanian di Desa Jono Oge.} Dari hasil wawancara, diketahui bahwa hingga saat ini belum ada upaya pemerintah yang memberikan dampak signifikan dalam memulihkan kembali kondisi lahan pertanian warga masyarakat. Upaya masih terfokus dalam memperbaiki infrastuktur berupa saluran irigasi yang diperkirakan membutuhkan waktu yang cukup lama.

Di sisi lain, adanya pemetaan daerah rawan bencana oleh pemerintah daerah belum terlalu banyak berdampak terhadap aktivitas warga. Hal ini disebabkan oleh adanya kebutuhan hidup warga yang mendesak sehingga aspek keselamatan belum begitu dipedulikan. Selain itu, kondisi keamanan juga diharapkan dapat berlangsung kondusif karena petani dapat melaksanakan aktivitasnya dengan baik apabila hal ini terwujud. Sejumlah petani menyampaikan bahwa saat ini kondisi keamanan sedikit terganggu seperti adanya kehilangan barang-barang milik petani yang digunakan untuk melaksanakan aktivitasnya.
Hal ini dapat dipahami karena sebagian besar petani menyewa lahan di desa terdekat dan tetap tinggal di Desa Jono Oge.

\section{KESIMPULAN}

Dari hasil penelitian ini diketahui dampak bencana alam yaitu gempa bumi dan likuifaksi terhadap petani di Desa Jono Oge sebagai berikut:

1. Gempa bumi dan likuifaksi sangat berdampak pada kehidupan para petani di Desa Jono Oge karena seluruh lahan pertanian mengalami kerusakan parah sehingga hal ini sangat berpengaruh terhadap produktivitas dan pola bertani masyarakat.

2. Gempa bumi dan likuifaksi menyebabkan pendapatan petani mengalami penurunan drastis hingga 50\% dari rata-rata sekitar 10 juta per bulan menjadi 5 juta per bulan.

3. Setelah gempa bumi dan likuifaksi seluruh petani tidak bisa menggunakan lahan yang dimiliki sehingga harus menyewa lahan petani yang ada di desa sekitar serta menggunakan peralatan Alcon untuk memperoleh air tanah dalam mengairi lahan pertanian.

4. Salah satu faktor pendukung kehidupan petani di Desa Jono Oge adalah adanya pengetahuan petani tentang manajemen serta teknologi pertanian sehingga aktivitas pertanian dapat tetap berjalan walaupun dalam kondisi yang terbatas.

\section{DAFTAR PUSTAKA}

Arisena, G.K.M. 2018. Pengantar Statistika. Program Studi Agribisnis Universitas Udayana, Bali.

Asy'ari, Q. (2018). Analisis Dampak Sosial Ekonomi Pasca Bencana Di Kabupaten Pamekasan (Studi Kasus Banjir, Longsor dan Kekeringan di Pamekasan 2007). Journal of Management and Accounting, Vol. 1(2), 151-168

Arumí, J. L., Rivera, D., Holzapfel, E., Boochs, P., Billib, M., \& Fernald, A. (2009). Effect of the Irrigation Canal Network on Surface and Groundwater Interactions in the Lower Valley of the Cachapoal River, Chile. Chilean Journal of Agricultural Research, 69 (1).

Badan Pusat Statistik Provinsi Sulawesi Tengah.2018. Provinsi Sulawesi Tengah Dalam Angka. BPS Provinsi Sulawesi Tengah, Palu. 
Bao, H., Ampuero, J-P., Meng, L., Fielding, E.J., Liang, C., Milliner, C.W.D., Feng, T., and Huang, H. 2019. Early and persistent supershear rupture of the 2018 magnitude 7.5 Palu earthquake. Nature Geoscience, Vol. 12, 200-205

Chapagain, T., \& Raizada, M. N. (2017). Impacts of natural disasters on smallholder farmers: gaps and recommendations. Agriculture \& Food Security, 6(1).

Codó, E. (2009). Interviews and Questionnaires. In L. Wei \& M. G. Moyer (Eds.), The Blackwell Guide to Research Methods in Bilingualism and Multilingualism (pp. 158-176).

Cohen, L. (2013). Research Methods in Education (7th ed.). https: 10.4324/9780203720967

https://news.okezone.com/read/2018/11/07/340/1974427/kembali-dari-pengungsian-warga-jono oge-bangun-hunian-sementara. Diakses tanggal 16 Mei 2019.

http://palu.tribunnews.com/2019/03/14/7000-hektare-lahan-kering-di-sigi-ketahanan-pangan-danekonomi-petani-bakal-kena-imbasnya. Diakses tanggal 16 Mei 2019.

https://properti.kompas.com/read/2018/10/09/161500221/data-osm-likuefaksi-di-desa-jono-ogeseluas-43687-hektar. (2019). Diakses tanggal 16 Mei 2019

Islam, M. M., \& Ahmed, S. (2017). Effects of Natural Disaster on Food Availability, Accessibility and Consumption in Household Level of Coastal Villages. Journal of Geography \& Natural Disasters, 7(3).

Kouadio, I. K., Aljunid, S., Kamigaki, T., Hammad, K., \& Oshitani, H. (2012). Infectious diseases following natural disasters: prevention and control measures. Expert Review of AntiInfective Therapy, 10(1), 95-104.

Mata-Lima, H., Alvino-Borba, A., Pinheiro, A., Mata-Lima, A., \& Almeida, J. A. (2013). Impactos dos desastres naturais nos sistemas ambiental e socioeconômico: o que faz a diferença? Ambiente \& Sociedade, 16(3), 45-64.

Minikel-Lacocque, J. (2018). The Affect-Responsive Interview and In-Depth Interviewing: What We Can Learn From Therapy Research. Qualitative Inquiry, 107780041879294.

Mulyati, H.2014. Analisis Produksi dan Pendapatan Usahatani Padi Sawah di Desa Jono Oge Kecamatan Sigi Biromaru Kabupaten Sigi . e-J. Agrotekbis 2 (1), 56-61

Padli, J., Shah Habibullah, M., \& Baharom, A. H. (2010). Economic impact of natural disasters' fatalities. International Journal of Social Economics, 37 (6), 429-441.

Panwar, V., \& Sen, S. (2019). Economic Impact of Natural Disasters: An Empirical Reexamination. Margin: The Journal of Applied Economic Research, 13(1), 109-139

Saputra, M.D, Antara, M dan Effendy. 2018. Dampak Program Pajala Terhadap Produktivitas Padi Sawah Di Desa Jono Oge Kecamatan Sigi Biromaru Kabupaten Sigi. J. Agroland, 25 (2), 96-105.

Sassa, S., dan Takagawa, T. 2019. Liquefied gravity flow-induced tsunami: first evidence and comparison from the 2018 Indonesia Sulawesi earthquake and tsunami disasters. Landslides, Vol. 16 (1), pp 195-200.

Scanlon, B. R., Faunt, C. C., Longuevergne, L., Reedy, R. C., Alley, W. M., McGuire, V. L., \& McMahon, P. B. (2012). Groundwater depletion and sustainability of irrigation in the US High Plains and Central Valley. Proceedings of the National Academy of Sciences, 109 (24), 9320-9325. 
Siebert, S., Burke, J., Faures, J. M., Frenken, K., Hoogeveen, J., Döll, P., \& Portmann, F. T. (2010). Groundwater use for irrigation - a global inventory. Hydrology and Earth System Sciences, 14(10), 1863-1880. https://doi.org/10.5194/hess-14-1863-2010

Valkaniotis, S., Ganas, A., Tsironi, V., Aggeliki, dan Barberopoulou. 2019. A preliminary report on the M 7.5 Palu earthquake co-seismic ruptures and landslides using image correlation techniques on optical satellite data. Diakses dari https://www.researchgate.net/publication/328414705 pada 20 Mei 2019

van der Hoek, W., Konradsen, F., Ensink, J. H. J., Mudasser, M., \& Jensen, P. K. (2001). Irrigation water as a source of drinking water: is safe use possible? Tropical Medicine and International Health, 6(1), 46-54. https://doi.org/10.1046/j.1365-3156.2001.00671.x

Voutsina, C. (2018). A practical introduction to in-depth interviewing.International Journal of Research \& Method in Education, 41(1), 123-124

Wekke, I.S, Sabara, Z., Samad, M.A., Yani, A., Abbas, T., dan Umam, R. 2019. Earthquake, Tsunami, and Society Cooperation: Early Findings in Palu Post of Indonesia Disaster. Makalah Dipresentasikan pada International Conference on Challenges and Opportunities of Sustainable Environmental Development (ICCOSED), Universitas Prof. Dr. Moestopo (Beragama), Jakarta, Indonesia, 11-13 January 2019. 